\title{
Genetic relationships between A20/INFAIP3, chronic inflammation and autoimmune disease
}

\author{
Lars Vereecke, Rudi Beyaert ${ }^{1}$ and Geert van Loo ${ }^{1}$ \\ Department for Molecular Biomedical Research, Unit of Molecular Signal Transduction in Inflammation, VIB, B-9052 Ghent, Belgium, and Department of \\ Biomedical Molecular Biology, Ghent University, B-9052 Ghent, Belgium
}

\begin{abstract}
A20 [also known as TNFAIP3 (tumour necrosis factor $\alpha$-induced protein 3)] restricts and terminates inflammatory responses through modulation of the ubiquitination status of central components in NF- $\kappa \mathrm{B}$ (nuclear factor $\kappa$ B), IRF3 (interferon regulatory factor 3 ) and apoptosis signalling cascades. The phenotype of mice with full or conditional $A 20$ deletion illustrates that A20 expression is essential to prevent chronic inflammation and autoimmune pathology. In addition, polymorphisms within the $A 20$ genomic locus have been associated with multiple inflammatory and autoimmune disorders, including SLE (systemic lupus erythaematosis), RA (rheumatoid arthritis), Crohn's disease and psoriasis. A20 has also been implicated as a tumour suppressor in several subsets of B-cell lymphomas. The present review outlines recent findings that illustrate the effect of A20 defects in disease pathogenesis and summarizes the identified A20 polymorphisms associated with different immunopathologies.
\end{abstract}

\section{Introduction}

The NF- $\kappa \mathrm{B}$ (nuclear factor $\kappa \mathrm{B}$ ) family of transcription factors plays a key role in controlling inflammatory and immune responses [1]. NF- $\kappa \mathrm{B}$ activation can proceed by two distinct signalling cascades. Canonical NF- $\kappa \mathrm{B}$ signalling is induced in response to pro-inflammatory cytokines [e.g. TNF (tumour necrosis factor)] and microbial infection and induces the expression of mainly pro-inflammatory and survival genes, whereas non-canonical NF- $\kappa \mathrm{B}$ signalling is initiated by a subset of receptors (e.g. lymphotoxin $\beta$ ) and mainly regulates the development of lymphoid organs and adaptive immune responses [2]. Because A20 has been described as a regulator of canonical NF- $\kappa$ B signalling, the focus of the present review is on this pathway. In the canonical pathway, NF- $\kappa \mathrm{B}$ dimers are sequestered in the cytoplasm by binding to $\mathrm{I} \kappa \mathrm{B}$ (inhibitor of NF- $\kappa \mathrm{B}$ ) proteins, of which $\mathrm{I} \kappa \mathrm{B} \alpha$ is the best known. Upon encountering an inflammatory stimulus such as TNF or LPS (lipopolysaccharide), $\mathrm{I} \kappa \mathrm{B} \alpha$ is phosphorylated followed by its ubiquitination and proteasomal degradation, releasing NF$\kappa \mathrm{B}$ for migration to the nucleus where it can drive gene expression [1]. Different receptors activate distinct NF- $\kappa B$ signalling pathways, which all converge at a central IKK ( $\mathrm{I} \kappa \mathrm{B}$ kinase) complex composed of two related kinases, IKK1 and IKK2 (also known as IKK $\alpha$ and $\operatorname{IKK} \beta$ ), and a regulatory

Key words: A20, autoimmunity, B-cell, inflammatory bowel disease (IBD), nuclear factor $\kappa \mathrm{B}$ (NF- $\kappa$ B), tumour necrosis factor $\alpha$-induced protein 3 (TNFAIP3).

Abbreviations used: DSS, dextran sodium sulfate; DUB, deubiquitinating; GWAS, genome-wide association study; IBD, inflammatory bowel disease; $1 \kappa \mathrm{B}$, inhibitor of nuclear factor $\kappa \mathrm{B}$; IKK, $1 \kappa \mathrm{B}$ kinase; IRF3, interferon regulatory factor 3; NEMO, nuclear factor $\kappa$ B essential modulator; NF$\kappa \mathrm{B}$, nuclear factor $\kappa \mathrm{B}$; NLR, Nod (nucleotide-binding oligomerization domain)-like receptor; PRR, pattern-recognition receptor; RA, rheumatoid arthritis; SLE, systemic lupus erythaematosis; SNP, single nucleotide polymorphism; TLR, Toll-like receptor; TNF, tumour necrosis factor; TNFAIP3, TNF $\alpha$-induced protein 3; TNIP1, TNFAIP3-interacting protein 1.

${ }^{1}$ Correspondence may be addressed to either of these authors (email rudi.beyaert@dmbr.vib-UGent.be or geert.vanloo@dmbr.vib-UGent.be). subunit NEMO (NF- $\kappa \mathrm{B}$ essential modulator, also known as IKK $\gamma$ ).

Defects in the regulation of $\mathrm{NF}-\kappa \mathrm{B}$-dependent gene expression contribute to a variety of diseases, including inflammatory and autoimmune diseases, neurological disorders and cancer. A tight regulation of NF- $\kappa \mathrm{B}$ signalling is thus absolutely required. To achieve this, cells employ different control mechanisms to keep NF- $\kappa \mathrm{B}$ signalling in check [3]. In this context, the ubiquitin-editing protein $\mathrm{A} 20$ [also known as TNFAIP3 (TNF $\alpha$-induced protein 3)] has been described as a key player in the termination of NF- $\kappa \mathrm{B}$ signalling and pro-inflammatory gene expression [4].

A20/TNFAIP3 is a cytoplasmic zinc-finger protein that is induced under inflammatory conditions and acts as a negative-feedback regulator of NF- $\kappa$ B activation in response to multiple stimuli, including TNF, IL (interleukin)-1, TLR (Toll-like receptor) and NLR [Nod (nucleotide-binding oligomerization domain)-like receptor] ligands. A20 was also shown to control antiviral signalling by acting as a negative regulator of IRF3 (interferon regulatory factor 3 ) signalling [5]. In addition to its NF- $\kappa$ B and IRF3 inhibitory properties, A20 is also a strong inhibitor of TNF-induced apoptosis [6]. The physiological importance of A20 as an anti-inflammatory protein is clearly demonstrated by the phenotype of A20-deficient mice, which are cachexic and develop severe multi-organ inflammation causing premature lethality [7]. Although little is known on the molecular mechanisms by which A20 controls apoptotic signalling, A20's NF- $\kappa$ B-inhibitory activities were shown to depend on its ubiquitin-editing function. The $\mathrm{N}$-terminus has DUB (deubiquitinating) activity and can inhibit NF- $\kappa \mathrm{B}$ signalling by removing Lys $^{63}$-linked polyubiquitin chains from specific NF- $\kappa \mathrm{B}$ signalling molecules [8]. The C-terminal zinc-finger-containing domain, however, possesses E3 
Figure 1 | Localization of polymorphisms associated with human immunopathologies in and around A20/TNFAIP3

The nine exons of human $A 20$ are represented as black/grey boxes, with the intronic regions in between. Untranslated exons are represented in grey. A schematic overview of the protein domains corresponding to specific exons of A20 is displayed below the genomic structure. The N-terminal OTU (ovarian tumour) domain is essential for DUB activity and the C-terminal zinc finger (ZF 1-7) domains mediate E3 ubiquitin-ligase activity.

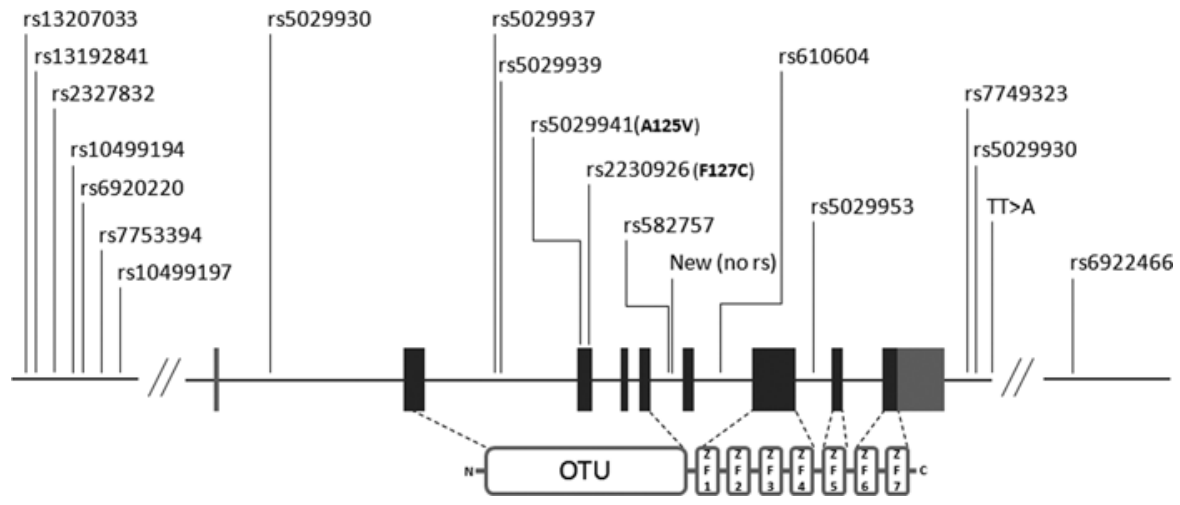

ubiquitin-ligase activity, promoting Lys $^{48}$-linked polyubiquitination followed by proteasome-mediated degradation of its target [8]. Recently, A20 was also shown to affect the ubiquitination status of signalling proteins by preventing the interaction between E2 ubiquitin-conjugating enzymes and E3 ubiquitin ligases via competitive binding [9]. More information on the molecular mechanisms of NF- $\kappa \mathrm{B}$ signalling and its regulation can be found elsewhere (e.g. [6]).

\section{A20 and intestinal mucosal biology}

Our intestinal microbiome poses a serious challenge to our immune system. The intestinal epithelium acts as a permeable barrier for efficient absorption of nutrients, but, at the same time, remains impermeable for luminal antigens, bacteria and bacterial products. Luminal bacteria are sensed by specialized innate immune receptors, called PRRs (pattern-recognition receptors), which are expressed by the epithelium and include TLRs, NLRs and C-type lectin receptors. Basal PRR stimulation leads to homoeostatic $\mathrm{NF}-\kappa \mathrm{B}$ signalling which does not cause spontaneous inflammation, but regulates intestinal barrier stability, epithelial proliferation, anti-microbial peptide production and antiapoptotic responses [10]. This protective function of NF$\kappa \mathrm{B}$ in the intestinal epithelium is clearly demonstrated in mice that specifically lack NEMO or both IKK1 and IKK2 in the intestinal epithelium, and which develop spontaneous intestinal inflammation due to increased epithelial apoptosis, leading to bacterial mucosal infiltration [11]. We showed recently that specific deletion of $\mathrm{A} 20$ in the intestinal epithelium also increased the sensitivity of the epithelium to apoptosis [12]. Although these mice develop normally without any sign of spontaneous intestinal inflammation, they are hypersensitive to DSS (dextran sodium sulfate)induced colitis and are unable to recover from DSS-induced intestinal damage. This DSS-hypersensitivity is associated with increased epithelial apoptosis [12]. Additionally, lowdose TNF injection causes massive epithelial apoptosis, leading to bacterial infiltration, bacteraemia and lethal sepsis within hours [12]. Interestingly, A20 expression is low at birth, and is strongly induced when the intestine becomes colonized by commensal bacteria [13]. In agreement with our observations in enterocyte-specific A20-deficient mice, it was shown that lethal inflammation in full A20knockout mice is also triggered by the bacterial commensal flora initiating pro-inflammatory cytokine production and systemic inflammation [14]. Together, these data show that A20 in enterocytes mainly acts as a cytoprotective protein and suggest that defects in A20 expression or function could contribute to intestinal pathology.

Evidence for a role of A20 in human intestinal pathology also came from recent genetic studies identifying $A 20$ as a susceptibility locus for IBD (inflammatory bowel disease) (Table 1 and Figure 1). A linkage analysis study on 260 IBD patients from 139 Caucasian families associated a region of human chromosome $6 \mathrm{q}$, containing the $A 20$ gene, to IBD [15]. In addition, a GWAS (genome-wide association study) for seven major common inflammatory diseases, on British people by the Wellcome Trust Case Control Consortium, identified A20 as a susceptibility gene for Crohn's disease [16]. Expression analysis on mucosal biopsies from 69 Crohn's disease patients confirmed a consistent down-regulation of A20 [17], further indicating reduced or defective A20 function in IBD. Recently, a novel non-synonymous mutation in African-American patients in exon $3(\mathrm{~A} 125 \mathrm{~V})$ was found to be associated with increased risk of IBD, whereas the same mutation was protective for SLE (systemic lupus erythaematosis) [18]. Computer modelling predicted that this amino acid change could alter the DUB activity of A20, affecting its proper function [18]. Interestingly, an SNP (single nucleotide polymorphism) in the $A 20$ locus was also 
Table 1 | Genetic variants in or near A20/INFAIP3 (138188581-138204449) associated with different immunopathologies in humans (based on NCBI SNP database)

\begin{tabular}{|c|c|c|c|c|}
\hline SNP & Location & Nucleotide & Position & Disease association \\
\hline 「s13207033 & 223 kb upstream & $\mathrm{A} / \mathrm{G}$ & 137965418 & RA \\
\hline 「s13192841 & 221 kb upstream & $A / G$ & 137967214 & SLE \\
\hline rs2327832 & 215 kb upstream & $\mathrm{A} / \mathrm{G}$ & 137973068 & $\begin{array}{l}\text { Coeliac disease } \\
\text { RA }\end{array}$ \\
\hline 「s10499194 & 186 kb upstream & $\mathrm{C} / \mathrm{T}$ & 138002637 & $\begin{array}{l}\text { RA } \\
\text { Juvenile idiopathic arthritis } \\
\text { SLE/RA: } \\
\text { Type } 1 \text { diabetes }\end{array}$ \\
\hline 「s6920220 & 182 kb upstream & $A / G$ & 138006503 & $\begin{array}{l}\text { RA } \\
\text { Juvenile idiopathic arthritis } \\
\text { Type } 1 \text { diabetes } \\
\text { SLE }\end{array}$ \\
\hline 「s7753394 & 103 kb upstream & $\mathrm{C} / \mathrm{T}$ & 138085248 & Crohn's disease \\
\hline 「s10499197 & 56 kb upstream & $\mathrm{G} / \mathrm{T}$ & 138132516 & SLE \\
\hline 「S5029930 & Intron 1 & $\mathrm{~A} / \mathrm{C}$ & 138190684 & $\begin{array}{c}\text { Coronary artery disease } \\
\text { in Type } 2 \text { diabetes }\end{array}$ \\
\hline 「S5029937 & Intron 2 & $\mathrm{G} / \mathrm{T}$ & 138195151 & RA \\
\hline 「s5029939 & Intron 2 & $\mathrm{C} / \mathrm{G}$ & 138195723 & $\begin{array}{l}\text { Systemic sclerosis } \\
\text { SLE }\end{array}$ \\
\hline 「S5029941 & Exon 3 & $\mathrm{C} / \mathrm{T}(\mathrm{A} 125 \mathrm{~V})$ & 138196060 & $\mathrm{SLE} / \mathrm{IBD} \dagger$ \\
\hline 「s2230926 & Exon 3 & $\mathrm{~T} / \mathrm{G}(\mathrm{F} 127 \mathrm{C})$ & 138196066 & SLE \\
\hline
\end{tabular}

\begin{tabular}{|c|c|c|c|c|c|}
\hline & & & & SLE/RA & Japanese [48] \\
\hline & & & & $\begin{array}{l}\text { Sjögren's } \\
\text { syndrome/Crohn's } \\
\text { disease/psoriasis/RA }\end{array}$ & European $[22] \ddagger$ \\
\hline Is582757 & Intron 5 & $A / G$ & 138197824 & Rheumatic heart disease & Chinese [55] \\
\hline New (no rs) & Intron 5 & $C /-$ & 138197889 & RA & European $[22] \ddagger$ \\
\hline rs610604 & Intron 6 & $\mathrm{~A} / \mathrm{C}$ & 138199417 & Psoriasis & Caucasian [34] \\
\hline & & & & $\begin{array}{l}\text { Coronary artery disease in } \\
\text { Type } 2 \text { diabetes }\end{array}$ & American [50] \\
\hline rs5029953 & Intron 7 & $A / G$ & 138200760 & SLE & African-American [18] \\
\hline 「s7749323 & 26 kb downstream & $A / G$ & 138230389 & SLE & European [23] \\
\hline 「s5029930 & 28 kb downstream & $\mathrm{A} / \mathrm{C}$ & 138232377 & $\begin{array}{l}\text { Coronary artery disease in } \\
\text { Type } 2 \text { diabetes }\end{array}$ & American [50] \\
\hline Polymorphic dinucleotide & 68 kb downstream & $\mathrm{TT}>\mathrm{A}$ & $138272732-138271733$ & SLE & European/Korean [29] \\
\hline rs6922466 & 256 kb downstream & $A / G$ & 138444930 & SLE & European [24] \\
\hline
\end{tabular}


identified as a risk factor in coeliac disease [19-21]. Finally, the non-synonymous SNP rs2230926/F127C was found to be associated with Crohn's disease in a Caucasian population with multiple autoimmune diseases [22] (Table 1).

In conclusion, the combined data from mouse disease models and human IBD samples identify A20 as a protein important for intestinal immune homoeostasis, and suggest that A20 deficiency or dysfunction could sensitize for IBD development. A20 restricts aberrant TLR- and NLR-induced $\mathrm{NF}-\kappa \mathrm{B}$ signalling in mucosal immune cells in response to the commensal microbiota, thereby preventing the production of harmful pro-inflammatory cytokines, and preserves intestinal barrier integrity in inflammatory conditions by preventing enterocyte apoptosis. On the basis of these findings, local enhancement of A20 function in the intestinal mucosa might therefore be a promising therapeutic strategy for the treatment of IBD.

\section{A20 and autoimmune diseases}

Next to the above described association of A20 with IBD and coeliac pathology, several more polymorphisms in or near the $A 20$ locus were described as being associated with inflammatory autoimmune pathology, including SLE $[23,24]$, RA (rheumatoid arthritis) $[25,26]$, psoriasis, multiple sclerosis [27] and Type 1 diabetes [28]. We recently published an overview of, at that time, all known A20 polymorphisms associated with disease [4]. Many of these have since been confirmed by multiple independent studies, often with patient and control cohorts from different populations. In addition, a number of new polymorphisms and mutations have been identified through genetic studies. An updated overview of the currently known diseaseassociated polymorphisms in the $A 20$ genomic locus is provided in Table 1 and Figure 1.

Most of the disease-associated $A 20$ polymorphisms reside outside the $A 20$ gene or in intronic sequences (Figure 1). Only two non-synonymous SNPs were found, in very close proximity in exon 3. These two SNPs (rs2230926/F127C and rs5029941/A125V) both affect the N-terminal DUB domain of A20, and functional studies on the SLE-associated F127C and A125V mutations were found to result in decreased inhibitory activity of A20 [18,24]. Using computer models, the structural implications of both mutations were predicted, showing that the $\mathrm{A} 125 \mathrm{~V}$ mutation could lead to conformational changes affecting the nearby catalytic core of the DUB domain, whereas the F127C mutation could influence the binding of target proteins [18]. In a recent study, all exons of TNFAIP3 were sequenced in a collection of 123 individuals with multiple autoimmune diseases and 397 unrelated healthy controls, identifying 11 new coding variants, of which eight are non-synonymous mutations spread over the entire coding sequence [22]. This study also identified the F127C coding SNP as a mutation associated with the risk of Sjögren's syndrome, Crohn's disease, psoriasis and RA [22]. Additionally, a novel SLE-associated haplotype (TT $>$ A) was recently identified in a conserved regulatory region downstream of $A 20$, which results in reduced A20 expression. This polymorphism results in reduced DNA binding of NF- $\kappa \mathrm{B}$ protein complexes [29].

The SLE-associated SNP (rs2230926) was first identified in Caucasians and was recently confirmed in a Chinese Han population [30]. The same GWAS identified some new SLE-susceptibility loci. One of the newly identified SNPs (rs10036748) is located in the TNIP1 (TNFAIP3-interacting protein 1), also known as $A B I N 1$ (A20-binding inhibitor of NF- $\kappa \mathrm{B}$ ) locus, an A20-binding inhibitor of NF- $\kappa \mathrm{B}$ and apoptosis signalling [31]. Another TNIP1 SNP (rs7708392) associated with SLE risk was identified in a Caucasian population [32] and confirmed in a Japanese population [33]. Together with A20, TNIP1 was also identified as a susceptibility gene for psoriasis [34]. It is worth mentioning that several genetic loci have been associated with more than one immunopathology, and many autoimmune patients are affected by multiple autoimmune diseases [22] (Table 1).

\section{A20 and B-cell biology}

Persistent $\mathrm{NF}-\kappa \mathrm{B}$ activation has a critical role in cancer development and progression [35]. Different genetic studies have suggested a role for A20 as a tumour suppressor, since A20 inactivation by somatic mutations and/or deletions, leading to constitutive $\mathrm{NF}-\kappa \mathrm{B}$ activation, is a frequent event in several subsets of B-cell lymphomas [36-39].

To study the role of A20 in lymphomagenesis, we and others generated B-cell-lineage-specific A20-knockout mice [40-42]. All three studies show that B-cell-specific A20 deficiency enhances B-cell proliferation and survival and leads to an autoimmune pathology, but does not lead to the spontaneous development of B-cell lymphomas. A20-deficient B-cells show increased CD40-, BCR- (B-cell receptor) and TLR-induced NF- $\kappa$ B responses in vitro [40-42]. Remarkably, according to Tavares et al. [40], A20-deficient B-cell survival results from the resistance of $\mathrm{B}$-cells to Fas-induced apoptosis due to increased NF- $\kappa \mathrm{B}$-dependent expression of the antiapoptotic protein Bcl-x. Moreover, their mice developed a lupus-like autoimmune pathology characterized by elevated numbers of germinal centre B-cells, autoantibodies and glomerular immunoglobulin deposits [40]. In contrast with these findings, studies with our A20-deficient mice show development of a progressive inflammatory phenotype, leading to an autoimmune syndrome only in old mice [41]. These mice do not display significant levels of antibodies against nuclear self-antigens (ANAs), which are the most common autoantibodies observed in SLE, but a general IgG autoreactivity to cardiolipin (diphosphatidylglycerol), a common autoantigen in autoimmune disease [41].

The fact that B-cell-specific A20-knockout mice do not develop B-cell lymphomas in naive conditions suggests that A20 deficiency may sensitize to lymphomagenesis only in cooperation with other B-cell oncogenes. Future studies should provide more insight into this aspect to clarify the role of A20 as a tumour suppressor in B-cells. 


\section{Concluding remarks}

A20 exerts both $\mathrm{NF}-\kappa \mathrm{B}$-inhibitory, IRF3-inhibitory and anti-apoptotic activities. GWASs have identified $A 20$ as a susceptibility gene for IBD, multiple autoimmune pathologies and subsets of B-cell lymphomas, and suggest that defects in A20 expression or function may contribute to disease pathogenesis. Although these genetic studies clearly define $A 20$ as a disease-susceptibility gene, more functional studies are needed to clarify the importance of A20 in disease pathogenesis. Mice lacking A20 in specific cell types or expressing mutant versions of A20 are important tools in these studies and will be very helpful to clarify the mechanisms by which A20 exerts its protective actions. Data from full A20-knockout mice suggest that the lethal phenotype is the consequence of uncontrolled innate immune responses triggered by intestinal bacteria, underscoring an essential anti-inflammatory function of A20 in these cells $[7,14]$. In contrast, A20 is dispensable for intestinal tissue development and enterocyte homoeostasis, but essential as a protective protein in conditions of inflammatory pressure [12]. A20 deficiency in B-cells does not lead to lymphomagenesis, but increases B-cell responses and survival, leading to the development of autoimmune pathology $[40,41]$. Future studies using tissue- and cellspecific A20-knockout mice will help to clarify further the role of A20 in autoimmune and inflammatory pathology.

\section{Funding}

L.V. is a Ph.D. fellow with the Institute for the Promotion of Innovation by Science and Technology (IWT). Our work is supported by an FWO Odysseus Grant (to G.v.L.) and research grants from the Interuniversity Attraction Poles programme [grant number IAP6/18], the Fund for Scientific Research - Flanders (FWO), the Belgian Foundation against Cancer, the Strategic Basis Research programme of the IWT, the Centrum voor Gezwelziekten, the Charcot Foundation, the Concerted Research Actions (GOA) and Group-ID MRP of Ghent University.

\section{References}

1 Ghosh, S. and Hayden, M.S. (2008) New regulators of NF- $\kappa$ B in inflammation. Nat. Rev. Immunol. 8, 837-848

2 Hayden, M.S., West, A.P. and Ghosh, S. (2006) NF- $\kappa$ B and the immune response. Oncogene $\mathbf{2 5}$, 6758-6780

3 Renner, F. and Schmitz, M.L. (2009) Autoregulatory feedback loops terminating the NF- $\kappa$ B response. Trends Biochem. Sci. 34, 128-135

4 Vereecke, L., Beyaert, R. and van Loo, G. (2009) The ubiquitin-editing enzyme A20 (TNFAIP3) is a central regulator of immunopathology. Trends Immunol. 30, 383-391

5 Parvatiyar, K. and Harhaj, E.W. (2011) Regulation of inflammatory and antiviral signaling by A20. Microbes Infect. 13, 209-215

6 Verstrepen, L., Verhelst, K., van Loo, G., Carpentier, I., Ley, S.C. and Beyaert, R. (2010) Expression, biological activities and mechanisms of action of A20 (TNFAIP3). Biochem. Pharmacol. 80, 2009-2020

7 Lee, E.G., Boone, D.L., Chai, S., Libby, S.L., Chien, M., Lodolce, J.P. and Ma, A. (2000) Failure to regulate TNF-induced NF- $\kappa$ B and cell death responses in A20-deficient mice. Science $\mathbf{2 8 9}, 2350-2354$

8 Wertz, I.E., O'Rourke, K.M., Zhou, H., Eby, M., Aravind, L., Seshagiri, S., Wu, P., Wiesmann, C., Baker, R., Boone, D.L. et al. (2004) De-ubiquitination and ubiquitin ligase domains of A20 downregulate NF- $\kappa$ B signalling. Nature 430, 694-699
9 Shembade, N., Ma, A. and Harhaj, E.W. (2010) Inhibition of NF- $\kappa$ B signaling by $A 20$ through disruption of ubiquitin enzyme complexes. Science 327, 1135-1139

10 Abreu, M.T. (2010) Toll-like receptor signalling in the intestinal epithelium: how bacterial recognition shapes intestinal function. Nat. Rev. Immunol. 10, 131-144

11 Nenci, A., Becker, C., Wullaert, A., Gareus, R., van Loo, G., Danese, S., Huth, M., Nikolaev, A., Neufert, C., Madison, B. et al. (2007) Epithelial NEMO links innate immunity to chronic intestinal inflammation. Nature 446, 557-561

12 Vereecke, L., Sze, M., McGuire, C., Rogiers, B., Chu, Y., Schmidt-Supprian, M., Pasparakis, M., Beyaert, R. and van Loo, G. (2010) Enterocyte-specific A20 deficiency sensitizes to tumor necrosis factor-induced toxicity and experimental colitis. J. Exp. Med. 207, 1513-1523

13 Wang, J., Ouyang, Y., Guner, Y., Ford, H.R. and Grishin, A.V. (2009) Ubiquitin-editing enzyme A20 promotes tolerance to lipopolysaccharide in enterocytes. J. Immunol. 183, 1384-1392

14 Turer, E.E., Tavares, R.M., Mortier, E., Hitotsumatsu, O., Advincula, R., Lee, B., Shifrin, N., Malynn, B.A. and Ma, A. (2008) Homeostatic MyD88 dependent signals cause lethal inflammation in the absence of A20. J. Exp. Med. 205, 451-464

15 Barmada, M.M., Brant, S.R., Nicolae, D.L., Achkar, J.P., Panhuysen, C.I. Bayless, T.M., Cho, J.H. and Duerr, R.H. (2004) A genome scan in 260 inflammatory bowel disease-affected relative pairs. Inflamm. Bowel Dis. 10, 513-520

16 Wellcome Trust Case Control Consortium (2007) Genome-wide association study of 14,000 cases of seven common diseases and 3,000 shared controls. Nature 447, 661-678

17 Arsenescu, R., Bruno, M.E., Rogier, E.W., Stefka, A.T., McMahan, A.E., Wright, T.B., Nasser, M.S., de Villiers, W.J. and Kaetzel, C.S. (2008) Signature biomarkers in Crohn's disease: toward a molecular classification. Mucosal Immunol. 1, 399-411

18 Lodolce, J.P., Kolodziej, L.E., Rhee, L., Kariuki, S.N., Franek, B.S., McGreal, N.M., Logsdon, M.F., Bartulis, S.J., Рerera, M.A., Ellis, N.A. et al. (2010) African-derived genetic polymorphisms in TNFAIP3 mediate risk for autoimmunity. J Immunol. 184, 7001-7009

19 Trynka, G., Zhernakova, A., Romanos, J., Franke, L., Hunt, K.A., Turner, G., Bruinenberg, M., Heap, G.A., Platteel, M., Ryan, A.W. et al. (2009) Coeliac disease-associated risk variants in TNFAIP3 and REL implicate altered NF- $\kappa$ B signalling. Gut 58, 1078-1083

20 Dubois, P.C., Trynka, G., Franke, L., Hunt, K.A., Romanos, J., Curtotti, A., Zhernakova, A., Heap, G.A., Adany, R., Aromaa, A. et al. (2010) Multiple common variants for celiac disease influencing immune gene expression. Nat. Genet. 42, 295-302

21 Zhernakova, A. (2011) Meta-analysis of genome-wide association studies in celiac disease and rheumatoid arthritis identifies fourteen non-HLA shared loci. PLoS Genet. 7, e1002004

22 Musone, S.L., Taylor, K.E., Nititham, J., Chu, C., Poon, A., Liao, W., Lam, E.T., Ma, A., Kwok, P.Y. and Criswell, L.A. (2011) Sequencing of TNFAIP3 and association of variants with multiple autoimmune diseases. Genes Immun. 12, 176-182

23 Graham, R.R., Cotsapas, C., Davies, L., Hackett, R., Lessard, C.J., Leon, J.M., Burtt, N.P., Guiducci, C., Parkin, M., Gates, C. et al. (2008) Genetic variants near TNFAIP3 on 6q23 are associated with systemic lupus erythematosus. Nat. Genet. 40, 1059-1061

24 Musone, S.L., Taylor, K.E., Lu, T.T., Nititham, J., Ferreira, R.C., Ortmann, W., Shifrin, N., Petri, M.A., Kamboh, M.I., Manzi, S. et al. (2008) Multiple polymorphisms in the TNFAIP3 region are independently associated with systemic lupus erythematosus. Nat. Genet. 40, 1062-1064

25 Thomson, W., Barton, A., Ke, X., Eyre, S., Hinks, A., Bowes, J., Donn, R., Symmons, D., Hider, S., Bruce, I.N. et al. (2007) Rheumatoid arthritis association at $6 \mathrm{q} 23$. Nat. Genet. $\mathbf{3 9}, \mathbf{1 4 3 1 - 1 4 3 3}$

26 Plenge, R.M., Cotsapas, C., Davies, L., Price, A.L., de Bakker, P.I., Maller, J., Pe'er, I., Burtt, N.P., Blumenstiel, B., DeFelice, M. et al. (2007) Two independent alleles at 6 q23 associated with risk of rheumatoid arthritis. Nat. Genet. 39, 1477-1482

27 De Jager, P.L., Jia, X., Wang, J., de Bakker, P.I., Ottoboni, L., Aggarwal, N.T., Piccio, L., Raychaudhuri, S., Tran, D., Aubin, C. et al. (2009) Meta-analysis of genome scans and replication identify CD6, IRF8 and TNFRSF1A as new multiple sclerosis susceptibility loci. Nat. Genet. 41, 776-782

28 Fung, E.Y., Smyth, D.J., Howson, J.M., Cooper, J.D., Walker, N.M., Stevens, H., Wicker, L.S. and Todd, J.A. (2009) Analysis of 17 autoimmune disease-associated variants in type 1 diabetes identifies 6q23/TNFAIP3 as a susceptibility locus. Genes Immun. 10, 188-191 
29 Adrianto, I., Wen, F., Templeton, A., Wiley, G., King, J.B., Lessard, C.J. Bates, J.S., Hu, Y., Kelly, J.A., Kaufman, K.M. et al. (2011) Association of a functional variant downstream of TNFAIP3 with systemic lupus erythematosus. Nat. Genet. 43, 253-258

30 Han, J.W., Zheng, H.F., Cui, Y., Sun, L.D., Ye, D.Q., Hu, Z., Xu, J.H., Cai, Z.M., Huang, W., Zhao, G.P. et al. (2009) Genome-wide association study in a Chinese Han population identifies nine new susceptibility loci for systemic lupus erythematosus. Nat. Genet. 41, 1234-1237

31 Verstrepen, L., Carpentier, I., Verhelst, K. and Beyaert, R. (2009) ABINs: A20 binding inhibitors of NF- $\kappa$ B and apoptosis signaling. Biochem. Pharmacol. 78, 105-114

32 Gateva, V., Sandling, J.K., Hom, G., Taylor, K.E., Chung, S.A., Sun, X., Ortmann, W., Kosoy, R., Ferreira, R.C., Nordmark, G. et al. (2009) A large-scale replication study identifies TNIP1, PRDM1, JAZF1, UHRF1BP1 and IL10 as risk loci for systemic lupus erythematosus. Nat. Genet. $\mathbf{4 1}$ 1228-1233

33 Kawasaki, A., Ito, S., Furukawa, H., Hayashi, T., Goto, D., Matsumoto, I., Kusaoi, M., Ohashi, J., Graham, R.R., Matsuta, K. et al. (2010) Association of TNFAIP3 interacting protein 1, TNIP1 with systemic lupus erythematosus in a Japanese population: a case-control association study. Arthritis Res. Ther. 12, R174

34 Nair, R.P., Duffin, K.C., Helms, C., Ding, J., Stuart, P.E., Goldgar, D., Gudjonsson, J.E., Li, Y., Tejasvi, T., Feng, B.J. et al. (2009) Genome-wide scan reveals association of psoriasis with IL-23 and NF- $\kappa$ B pathways. Nat. Genet. 41, 199-204

35 Karin, M. (2006) Nuclear factor- $\kappa$ B in cancer development and progression. Nature 441, 431-436

36 Novak, U., Rinaldi, A., Kwee, I., Nandula, S.V., Rancoita, P.M., Compagno, M., Cerri, M., Rossi, D., Murty, V.V., Zucca, E. et al. (2009) The NF- $\kappa$ B negative regulator TNFAIP3 (A20) is inactivated by somatic mutations and genomic deletions in marginal zone lymphomas. Blood $\mathbf{1 1 3}$ 4918-4921

37 Kato, M., Sanada, M., Kato, I., Sato, Y., Takita, J., Takeuchi, K., Niwa, A., Chen, Y., Nakazaki, K., Nomoto, J. et al. (2009) Frequent inactivation of A20 in B-cell lymphomas. Nature 459, 712-716

38 Compagno, M., Lim, W.K., Grunn, A., Nandula, S.V., Brahmachary, M., Shen, Q., Bertoni, F., Ponzoni, M., Scandurra, M., Califano, A. et al. (2009) Mutations of multiple genes cause deregulation of $\mathrm{NF}-\kappa \mathrm{B}$ in diffuse large B-cell lymphoma. Nature 459, 717-721

39 Schmitz, R., Hansmann, M.L., Bohle, V., Martin-Subero, J.I., Hartmann, S., Mechtersheimer, G., Klapper, W., Vater, I., Giefing, M., Gesk, S. et al. (2009) TNFAIP3 (A20) is a tumor suppressor gene in Hodgkin lymphoma and primary mediastinal B cell lymphoma. J. Exp. Med. 206, 981-989

40 Tavares, R.M., Turer, E.E., Liu, C.L., Advincula, R., Scapini, P., Rhee, L., Barrera, J., Lowell, C.A., Utz, P.J., Malynn, B.A. and Ma, A. (2010) The ubiquitin modifying enzyme A20 restricts B cell survival and prevents autoimmunity. Immunity 33, 181-191

41 Chu, Y., Vahl, J.C., Kumar, D., Heger, K., Bertossi, A., Wojtowicz, E., Soberon, V., Schenten, D., Mack, B., Reutelshofer, M. et al. (2011) B cells lacking the tumor suppressor TNFAIP3/A20 display impaired differentiation, hyperactivation, cause inflammation and autoimmunity in aged mice. Blood 117, 2227-2236

42 Hovelmeyer, N., Reissig, S., Thi Xuan, N., Adams-Quack, P., Lukas, D., Nikolaev, A., Schluter, D. and Waisman, A. (2011) A20 deficiency in B cells enhances B-cell proliferation and results in the development of autoantibodies. Eur. J. Immunol. 41, 595-601

43 Coenen, M.J., Trynka, G., Heskamp, S., Franke, B., van Diemen, C.C., Smolonska, J., van Leeuwen, M., Brouwer, E., Boezen, M.H., Postma, D.S et al. (2009) Common and different genetic background for rheumatoid arthritis and coeliac disease. Hum. Mol. Genet. 18, 4195-4203
44 Hughes, L.B., Reynolds, R.J., Brown, E.E., Kelley, J.M., Thomson, B., Conn, D.L., Jonas, B.L., Westfall, A.O., Padilla, M.A., Callahan, L.F. et al. (2010) Most common single-nucleotide polymorphisms associated with rheumatoid arthritis in persons of European ancestry confer risk of rheumatoid arthritis in African Americans. Arthritis Rheum. 62, 3547-3553

45 van der Helm-van Mil, A.H., Toes, R.E. and Huizinga, T.W. (2010) Genetic variants in the prediction of rheumatoid arthritis. Ann. Rheum. Dis. 69 1694-1696

46 Stahl, E.A., Raychaudhuri, S., Remmers, E.F., Xie, G., Eyre, S., Thomson, B.P., Li, Y., Kurreeman, F.A., Zhernakova, A., Hinks, A. et al. (2010) Genome-wide association study meta-analysis identifies seven new rheumatoid arthritis risk loci. Nat. Genet. 42, 508-514

47 Prahalad, S., Hansen, S., Whiting, A., Guthery, S.L., Clifford, B., McNally, B., Zeft, A.S., Bohnsack, J.F. and Jorde, L.B. (2009) Variants in TNFAIP3, STAT4, and C120rf30 loci associated with multiple autoimmune diseases are also associated with juvenile idiopathic arthritis. Arthritis Rheum. 60, 2124-2130

48 Shimane, K., Kochi, Y., Horita, T., Ikari, K., Amano, H., Hirakata, M., Okamoto, A., Yamada, R., Myouzen, K., Suzuki, A. et al. (2010) The association of a nonsynonymous single-nucleotide polymorphism in TNFAIP3 with systemic lupus erythematosus and rheumatoid arthritis in the Japanese population. Arthritis Rheum. 62, 574-579

49 Morgan, A.W., Robinson, J.I., Conaghan, P.G., Martin, S.G., Hensor, E.M., Morgan, M.D., Steiner, L., Erlich, H.A., Gooi, H.C., Barton, A. et al. (2010) Evaluation of the rheumatoid arthritis susceptibility loci HLA-DRB1, PTPN22, OLIG3/TNFAIP3, STAT4 and TRAF1/C5 in an inception cohort. Arthritis Res. Ther. 12, R57

50 Boonyasrisawat, W., Eberle, D., Bacci, S., Zhang, Y.Y., Nolan, D., Gervino, E.V., Johnstone, M.T., Trischitta, V., Shoelson, S.E. and Doria, A. (2007) Tag polymorphisms at the A20 (TNFAIP3) locus are associated with lower gene expression and increased risk of coronary artery disease in type 2 diabetes. Diabetes 56, 499-505

51 Bowes, J., Lawrence, R., Eyre, S., Panoutsopoulou, K., Orozco, G., Elliott, K.S., Ke, X., Morris, A.P., Thomson, W., Worthington, J. et al. (2010) Rare variation at the TNFAIP3 locus and susceptibility to rheumatoid arthritis. Hum. Genet. 128, 627-633

52 Dieude, P., Guedj, M., Wipff, I., Ruiz, B., Riemekasten, G., Matucci-Cerinic, M., Melchers, I., Hachulla, E., Airo, P., Diot, E. et al. (2010) Association of the TNFAIP3 rs5029939 variant with systemic sclerosis in the European Caucasian population. Ann. Rheum. Dis. 69, 1958-1964

53 Fan, Y., Tao, J.H., Zhang, L.P., Li, L.H. and Ye, D.Q. (2011) The association between BANK1 and TNFAIP3 gene polymorphisms and systemic lupus erythematosus: a meta-analysis. Int. J. Immunogenet. 38, 151-159

54 Kawasaki, A., Ito, I., Ito, S., Hayashi, T., Goto, D., Matsumoto, I., Takasaki, Y., Hashimoto, H., Sumida, T. and Tsuchiya, N. (2010) Association of TNFAIP3 polymorphism with susceptibility to systemic lupus erythematosus in a Japanese population. J. Biomed. Biotechnol. 2010, 207578

55 Hua, R., Xu, J.B., Wang, J.C., Zhu, L., Li, B., Liu, Y., Huang, S.D., Jin, L., Xu, Z.Y. and Wang, X.F. (2009) Association of TNFAIP3 polymorphism with rheumatic heart disease in Chinese Han population. Immunogenetics $6 \mathbf{1}$, 739-744

Received 3 March 2011 doi:10.1042/BST0391086 